\title{
Mycoplasma corogypsi sp. nov., a New Species from the Footpad Abscess of a Black Vulture, Coragyps atratus
}

\author{
VICTOR S. PANANGALA, ${ }^{1 *}$ JOYCE S. STRINGFELLOW, ${ }^{1}$ KEVIN DYBVIG, ${ }^{2}$ ANN WOODARD, ${ }^{2}$ \\ FEI SUN, ${ }^{2}$ DAVID L. ROSE, ${ }^{3}$ AND MARTHA M. GRESHAM ${ }^{1}$ \\ Department of Pathobiology, College of Veterinary Medicine, Auburn University, Auburn, \\ Alabama 36849-5519'; Departments of Comparative Medicine and Microbiology, \\ University of Alabama at Birmingham, Birmingham, Alabama 352942; and Mycoplasma Section, \\ Laboratory of Molecular Microbiology, Frederick Cancer Research and Development Center, \\ National Institute of Allergy and Infectious Diseases, Frederick, Maryland $21712^{3}$
}

\begin{abstract}
Strain BV1 was isolated from the exudate of the footpad abscess of a black vulture (Coragyps atratus). The colonies had a "fried-egg" appearance consistent with that of mycoplasmal species. Electron microscopic examination of the cells revealed irregular elongated or elliptical forms and smaller circular budding processes. Profuse growth was observed in Frey medium supplemented with $20 \%$ swine serum at $37^{\circ} \mathrm{C}$ in a humidified atmosphere of $10 \% \mathrm{CO}_{2}$ and air. Typical of mycoplasma, strain $\mathrm{BV1}$ required sterol for growth and catabolized glucose but did not hydrolyze arginine or urea. The guanine-plus-cytosine content of the DNA was 28 mol\%. The organism demonstrated the ability to hemolyze, absorb onto, and agglutinate the erythrocytes from several animal species. Strain BV1 was serologically unrelated by the growth inhibition test to previously established Mycoplasma, Acholeplasma, Entomoplasma, and Mesoplasma species, as well as to strains belonging to these genera but not identified to species level. Moreover, BV1 had a 16S rRNA gene with a nucleotide sequence distinct from reported sequences of other mycoplasmas. This organism represents a new species for which the name Mycoplasma corogypsi is proposed. Strain BV1 (ATCC 51148 ${ }^{\mathrm{T}}$ ) is the type strain of Mycoplasma corogypsi sp. nov.
\end{abstract}

Cell wall-less procaryotes (in the class Mollicutes) have been previously isolated from a variety of domestic and free-living avian species $(2,9,17,18,25,34,38)$. Most of the known pathogenic and nonpathogenic species of Mollicutes isolated from avian hosts belong to the family Mycoplasmataceae and the genus Mycoplasma $(16,27)$. Species belonging to the genera Acholeplasma (34) and Ureaplasma (20) have been isolated less frequently from birds, and their role as pathogens remains vague.

We describe the characteristics of a mycoplasma isolated from the footpad abscess of a black vulture, Coragyps atratus. The black vulture is native to North America and subsists chiefly or entirely on carrion (33). On the basis of proposed standards for the description of new species of the class Mollicutes (15), we find that the mycoplasma isolated from the vulture possesses distinctive characteristics that differentiate it from other previously classified mycoplasma species. We therefore propose the recognition of strain BV1 (Mycoplasma corogypsi) as a new species in the genus Mycoplasma.

\section{MATERIALS AND METHODS}

Mycoplasma. The mycoplasma designated strain BV1 was isolated from an abscess in the footpad of a black vulture which was presented to the Raptor Rehabilitation Center, Auburn University, Auburn, Alabama. The abscess was incised surgically, and the exudate was initially cultured on blood agar base (Bacto Tryptose Blood Agar Base with yeast extract; Difco Laboratories, Detroit, Mich.) supplemented with $5 \%$ bovine blood. Other avian mycoplasma type cultures used for comparison in this study (Mycoplasma gallisepticum ATCC $19610^{\mathrm{T}}$, Mycoplasma synoviae ATCC

\footnotetext{
* Corresponding author.
}

$25204^{\mathrm{T}}$, Mycoplasma gallinarum ATCC $19708^{\mathrm{T}}$, Mycoplasma gallinaceum ATCC $33550^{\mathbf{T}}$, Mycoplasma meleagridis ATCC $25294^{\mathrm{T}}$, and Mycoplasma iowae ATCC $33552^{\mathrm{T}}$ ) were obtained from the American Type Culture Collection, Rockville, Md.

Media and growth conditions. Subculture of strain BV1 was done on Frey agar and broth medium (12) supplemented with $20 \%$ swine serum. The purified agar used in the solid medium was Oxoid bacteriological agar no. 1 (Oxoid, Ltd., Basingstoke, Hampshire, England), and the yeast extract was made from fresh baker's yeast. For subsequent growth and characterization, modified Frey medium or the medium recommended for the relevant test procedure was used. The cultures were incubated at $37^{\circ} \mathrm{C}$ in a humidified atmosphere with $10 \% \mathrm{CO}_{2}$ and air and under anaerobic conditions (GasPak; BBL Microbiology Systems, Cockeysville, Md.). After being filter cloned three times (15), liquid cultures were aliquoted and stored frozen at $-70^{\circ} \mathrm{C}$.

Morphological studies. Mycoplasma colonies grown on agar medium were examined with a stereo microscope after 2,4 , and 8 days of incubation. Colonies were also observed after being stained by the Dienes method (5). Liquid cultures were observed by dark-field, phase-contrast microscopy and by light microscopy after being stained by the Giemsa method (10). For electron microscopy, strain BV1 harvested from Frey broth cultures was fixed in $2 \%$ paraformaldehyde in $0.2 \mathrm{M}$ Tris-buffered saline solution (pH 7.5). After two washes in Tris-buffered saline, cells were postfixed with $1 \%$ (wt/vol) osmium tetroxide. The fixed cells were sequentially dehydrated in graded dilutions of ethanol and then embedded in vinyl cyclohexene dioxide epoxy resin (Spurr; Ladd Research Industries, Inc., Burlington, Vt.). Thin sections were collected on copper grids, stained with $10 \%$ uranyl acetate in methanol and $0.4 \%$ lead citrate, and observed with 
a Philips electron microscope (Philips International, Eindhoven, The Netherlands) at $60 \mathrm{kV}$.

Absence of reversion. Strain BV1 was subcultured through several passages in both solid and liquid media devoid of any antibiotics. After each passage, the cells were harvested by centrifugation and examined microscopically under darkfield conditions or after being stained by the Giemsa method. Colonies on solid agar were also examined after being stained by the Dienes method.

Filterability studies. A 24-h broth culture of strain BV1 was diluted in 10-fold steps in Frey medium and filtered through membrane filters (Millipore Corp., Bedford, Mass.) with pore diameters of 220 and $450 \mathrm{~nm}$. The total CFU/0.025 ml of each dilution cultured on agar plates was enumerated and compared with those of the original unfiltered dilutions.

Sterol requirement. A modification of the direct broth culture method (28) as described previously (19) was used for the determination of sterol dependence. Briefly, strain BV1 was washed twice in phosphate-buffered saline ( $\mathrm{pH} 7.2$ ) and cultured in serum-free medium containing graded concentrations $(1,5,10$, and $20 \mu \mathrm{g} / \mathrm{ml})$ of cholesterol. Medium containing $5 \%$ swine serum (growth control) and medium devoid of cholesterol and serum (reagent control) were similarly inoculated with strain BV1. For comparative evaluation of growth with and without cholesterol, parallel experiments with $M$. gallisepticum ATCC $19610^{\mathrm{T}}$ were conducted. The cultures were incubated for 6 days, and the protein content of the harvested cell pellets was determined by a modified Lowry procedure (22). Sensitivity to digitonin was determined by the disk-growth inhibition test (11).

Biochemical characteristics. The fermentation of glucose; hydrolysis of arginine, esculin, and urea; reduction of methylene blue, tetrazolium, and tellurite; liquefaction of coagulated serum; film and spot production; and phosphatase activity were determined according to procedures previously described $(1,26)$. M. gallisepticum ATCC $19610^{\mathrm{T}}$ cultured under the same conditions as strain BV1 was used as a control in each test.

Hemolysis, hemadsorption, and hemagglutination. The hemolytic activity, adsorption, and agglutination of erythrocytes by strain BV1 were evaluated with chicken, guinea pig, human, and sheep cells. The overlay technique was used to test for hemolysis (1). Hemadsorption was determined by the method described by Sobeslavsky et al. (32), and hemagglutination was assessed by the microtitration procedure (13).

Serological test. The disk-growth inhibition test was performed at the Mycoplasma Section, Laboratory of Molecular Microbiology, Research Development Center, National Institute of Allergy and Infectious Diseases, Frederick, Md., as described previously (3). Strain BV1 was cultured in SP-4 broth (35), plated on SP-4 agar, and tested against a panel of reference antisera as listed in Table 1.

Sodium dodecyl sulfate-polyacrylamide gel electrophoresis. The protein profile of strain BV1 was electrophoretically resolved by sodium dodecyl sulfate-polyacrylamide gel electrophoresis (21) and compared with the protein profiles of six recognized avian species: $M$. gallisepticum ATCC $19610^{\mathrm{T}}$, $M$. synoviae ATCC $25204^{\mathrm{T}}, M$. gallinarum ATCC $19708^{\mathrm{T}}$, $M$. gallinaceum ATCC $33550^{\mathrm{T}}, M$. meleagridis ATCC $25294^{\mathrm{T}}$, and $M$. iowae ATCC $33552^{\mathrm{T}}$.

DNA base composition. DNA was extracted from mycoplasmas as described previously (6). The $\mathrm{G}+\mathrm{C}$ content was determined from the buoyant density of the DNA in cesium chloride by ultracentrifugation (31). DNAs extracted from
TABLE 1. Biological and biochemical characteristics of strain BV1 and $M$. gallisepticum ATCC $19610^{\mathrm{T}}$

\begin{tabular}{|c|c|c|}
\hline \multirow{2}{*}{ Test or characteristic } & \multicolumn{2}{|c|}{ Result for ${ }^{a}$ : } \\
\hline & Strain BV1 & M. gallisepticum \\
\hline Colony morphology & Typical & Typical \\
\hline Dienes stain & + & + \\
\hline Digitonin sensitivity & + & + \\
\hline Glucose fermentation & + & + \\
\hline Arginine hydrolysis & - & - \\
\hline Urea utilization & - & - \\
\hline Phosphatase activity & - & - \\
\hline Film and spot formation & - & - \\
\hline Digestion of coagulated serum & - & - \\
\hline Tetrazolium reduction & $W^{a e} / W^{a n}$ & $+{ }^{a e} /+^{a n}$ \\
\hline Tellurite reduction & $+{ }^{a e} / t^{a n}$ & $++^{a e} / t^{a n}$ \\
\hline Esculin hydrolysis & + & + \\
\hline Methylene blue reduction & - & - \\
\hline Hemolysis $^{b}$ & Alpha & Alpha \\
\hline Hemadsorption $^{b}$ & + & + \\
\hline Hemagglutination $^{b}$ & + & + \\
\hline
\end{tabular}

$a+$, positive; - , negative; $W$, weak reaction; superscript ae, aerobically; superscript an, anaerobically.

${ }^{b}$ Each test performed with chicken, guinea pig, sheep, and human erythrocytes.

Mycoplasma pulmonis KD735 (7) and $M$. gallisepticum ATCC $19610^{\mathrm{T}}$ served as controls with known $\mathrm{G}+\mathrm{C}$ contents. Cloning and DNA sequencing. The 16S rRNA gene was enzymatically amplified from strain BV1 DNA by the polymerase chain reaction under conditions recommended by the supplier of Taq DNA polymerase and buffer (Perkin-Elmer Cetus Corp., Norwalk, Conn.). Reaction mixtures and thermal cycling conditions were as described previously (8). Polymerase chain reaction primers were the fD1 and rP1 oligonucleotides (36), which can be used to amplify nucleotides 8 through 1512 (Escherichia coli numbers) of the 16S rRNA gene from most eubacteria. A polymerase chain reaction product of the expected size $(1.5 \mathrm{~kb})$ was cloned into the Bam HI-SalI site (primer fD1 contains a SalI site, and primer rP1 contains a BamHI site) of plasmid pUC18 (24) by using conditions described elsewhere (30). Plasmid DNA was maintained in $E$. coli JM103 (23), isolated by the alkaline lysis method, and further purified by cesium chloride-ethidium bromide density gradient centrifugation (29). DNA sequencing was performed by the dideoxynucleotide chain termination method with a double-stranded DNA template and the Sequenase 2.0 kit (United States Biochemical Corp., Cleveland, Ohio). DNA oligonucleotide primers for sequencing were supplied by the Oligonucleotide Synthesis Core Facility of the University of Alabama at Birmingham. The nucleotide sequence of both strands of the insert was determined to ensure accuracy. Sequence analysis was performed by using the MacVector software package from International Biotechniques, Inc. (New Haven, Conn.), and the Genetics Computer Group programs (4).

Nucleotide sequence accession number. The sequence data reported here have been assigned GenBank accession number L08054.

\section{RESULTS}

Initial isolation. Strain BV1 was isolated from an abscess in the footpad of a black vulture (C. atratus). The initial isolation was made on blood agar in pure culture from the exudate of the surgically incised abscess. Minute colonies 


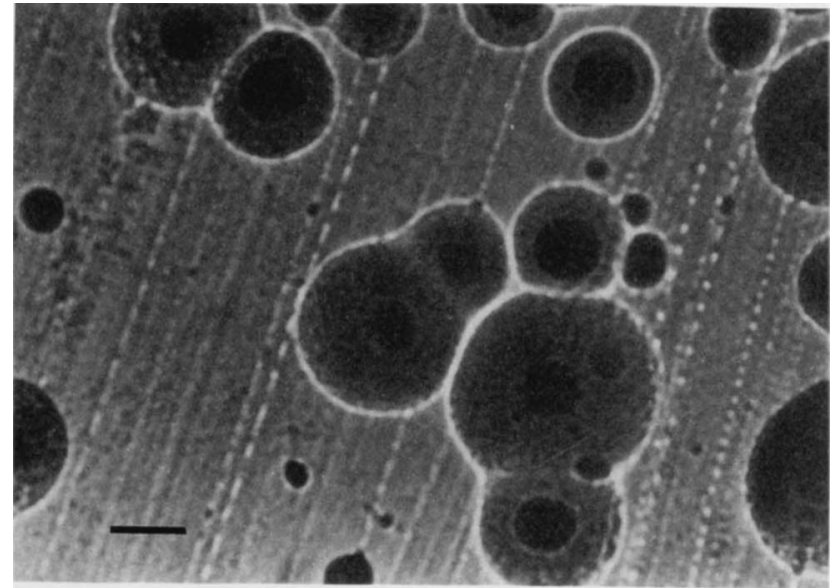

FIG. 1. Colonies of strain BV1 grown on Frey medium for $48 \mathrm{~h}$ as viewed by transmitted-light microscopy. Bar $=100 \mu \mathrm{m}$.

surrounded by alpha-hemolytic zones were observed on blood agar. Gram-stained smears of the colonies showed irregular pale-pink clusters without any distinct morphology.

Morphology and ultrastructure. Strain BV1 grew profusely in Frey medium at $37^{\circ} \mathrm{C}$ in an atmosphere of $10 \% \mathrm{CO}_{2}$ and air. Sparse growth was observed under anaerobic conditions. The colonies had a typical "fried-egg-like" shape on solid Frey medium within 24 to $48 \mathrm{~h}$ of incubation (Fig. 1). Colonies ranged from 20 to $450 \mu \mathrm{m}$ in diameter. Larger aggregates of colonies were also observed. A variation in colony size was apparent even after repeated filtrationcloning procedures. Giemsa-stained smears revealed minute coccoid elements and irregular clumps with no distinct morphology. Irregular clumps of organisms were also observed under phase-contrast and dark-field microscopy. Electron microscopy of thin sections revealed cells that were without cell walls and that were bounded by a single trilaminar membrane (Fig. 2). The cells were pleomorphic with irregular elongated or elliptical forms abounding and smaller

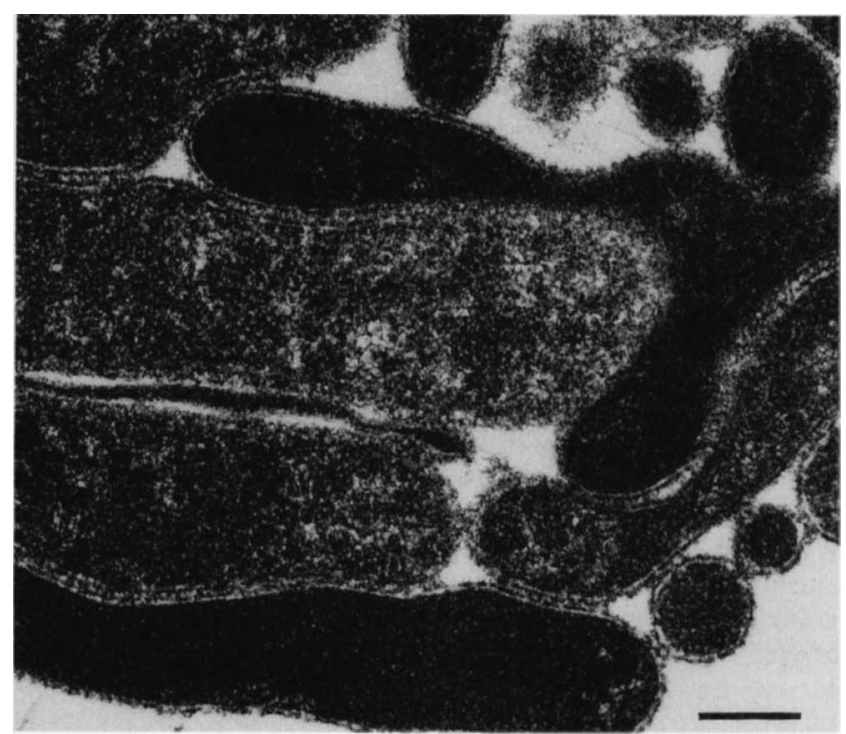

FIG. 2. Electron micrograph of thin section of strain BV1. Bar = $100 \mathrm{~nm}$. circular budding processes abutting the elongated cells (Fig. 2 ). The average dimensions of the cells ranged from 0.3 to 2.0 by 0.2 to $0.6 \mu \mathrm{m}$.

Reversion studies. Cultures of strain BV1 did not show any alteration in colony morphology or growth characteristics after repeated (10 consecutive) passages in antibiotic-free medium. Colonies transferred to blood agar without antibiotics did not show any signs of transformation to bacterial forms and maintained their original appearance when stained and examined microscopically. Dienes-stained colonies were deep blue.

Filtration studies. A culture of strain BV1 diluted 1:80 and plated on solid medium contained $4.8 \times 10^{7} \mathrm{CFU} / \mathrm{ml}$. The culture filtrate of the same dilution yielded $1.1 \times 10^{2} \mathrm{CFU} / \mathrm{ml}$ after filtration through a 220 -nm-pore-size filter and yielded $2.4 \times 10^{4} \mathrm{CFU} / \mathrm{ml}$ after filtration through a 450 -nm-pore-size filter.

Sterol requirement. Strain BV1 showed growth in the medium supplemented with 5,10 , or $20 \mu \mathrm{g}$ of cholesterol per $\mathrm{ml}$. Growth was also observed in the medium with $5 \%$ swine serum but was absent from serum- or cholesterol-free medium and from medium supplemented with $1 \mu \mathrm{g}$ of cholesterol per ml. Similar results were observed with $M$. gallisepticum ATCC $19610^{\mathrm{T}}$, which was used as a control. Sensitivity to digitonin was apparent by the lack of growth of strain BV1 in a zone exceeding $6 \mathrm{~mm}$ in diameter surrounding the disk impregnated with digitonin. The zone of inhibition for $M$. gallisepticum ATCC $19610^{\mathrm{T}}$ was $8 \mathrm{~mm}$ in diameter.

Biochemical and biological characteristics. Results of the biochemical and biological tests performed with strain BV1 are summarized in Table 1 . The results were compared with those for $M$. gallisepticum ATCC $19610^{\mathrm{T}}$.

Hemolysis, hemadsorption, and hemagglutination. Colonies of strain BV1 produced zones of alpha-hemolysis with chicken, guinea pig, human, and sheep erythrocytes. Adsorption of erythrocytes onto strain BV1 and agglutination were observed with erythrocytes from all of the species tested.

Serological test. The results of the growth inhibition test with a panel of antisera against recognized glucose-fermentative and -nonfermentative Mycoplasma and Acholeplasma species are presented in Table 2 . Included were antisera against nine previously described avian species (Mycoplasma anatis $1340^{\mathrm{T}}$, Mycoplasma columborale MMP-4 ${ }^{\mathrm{T}}, M$. gallinaceum $\mathrm{DD}^{\mathrm{T}}, M$. gallisepticum $\mathrm{PG} 31^{\mathrm{T}}$, Mycoplasma gallopavonis $\mathrm{WR}^{\mathrm{T}}$, M. iowae $695^{\mathrm{T}}$, Mycoplasma lipofaciens $\mathrm{R}^{171^{\mathrm{T}}}$, Mycoplasma pullorum $\mathrm{CKK}^{\mathrm{T}}$, and $M$. synoviae WVU $1853^{\mathrm{T}}$ ). Results indicated that strain BV1 was serologically unrelated to any of the Mycoplasma or Acholeplasma species tested.

Protein pattern by gel electrophoresis. To obtain comparable polypeptide patterns, the six avian mycoplasma type strains (M. gallisepticum ATCC $19610^{\mathrm{T}}, M$. synoviae ATCC $25204^{\mathrm{T}}, M$. gallinarum ATCC $19708^{\mathrm{T}}, M$. gallinaceum ATCC $33550^{\mathrm{T}}, M$. meleagridis ATCC $25294^{\mathrm{T}}$, and $M$. iowae ATCC $33552^{\mathrm{T}}$ ) and strain BV1 were cultured similarly in Frey medium and harvested at the end of $48 \mathrm{~h}$. More than 30 protein bands per track could be distinguished in Coomassie blue-stained gels (Fig. 3).

Base composition. The average $\mathrm{G}+\mathrm{C}$ content of strain BV1 as determined from three independent experiments was 28 mol\%. The $\mathrm{G}+\mathrm{C}$ contents of $\boldsymbol{M}$. pulmonis and $\boldsymbol{M}$. gallisepticum were 28 and $34 \mathrm{~mol} \%$, respectively, in agreement with previous reports (14).

16S rRNA gene. The nucleotide sequence of the strain BV1 
TABLE 2. Antisera to Mollicute strains used in serological comparison of strain $\mathrm{BV}^{a}$

Mycoplasma agalactiae PG2 ${ }^{T}$

Mycoplasma alkalescens $\mathrm{D} 12^{\mathrm{T}}$

Mycoplasma alvi Ilsley $^{\mathrm{T}}$

Mycoplasma anatis $1340^{\mathrm{T}}$

Mycoplasma anseris $1219^{\mathrm{T}}$

Mycoplasma arginini $\mathrm{G} 230^{\mathrm{T}}$

Mycoplasma arthritidis PG6 ${ }^{\mathrm{T}}$

Mycoplasma bovigenitalium $\mathrm{PG}^{\mathrm{T}}{ }^{\mathrm{T}}$

Mycoplasma bovirhinis $\mathrm{PG}{ }^{\mathrm{T}}$

Mycoplasma bovis Donetta ${ }^{\mathrm{T}}$

Mycoplasma bovoculi $\mathrm{M} 165 / 69^{\mathrm{T}}$

Mycoplasma buccale $\mathrm{CH} 20247^{\mathrm{T}}$

Mycoplasma californicum ST- $6^{\mathrm{T}}$

Mycoplasma canadense $275 \mathrm{C}^{\mathrm{T}}$

Mycoplasma canis PG14 ${ }^{\mathrm{T}}$

Mycoplasma capricolum California $\mathbf{K i d}^{\mathbf{T}}$

Mycoplasma caviae $\mathrm{G}^{122^{\mathrm{T}}}$

Mycoplasma cavipharyngis $117 \mathrm{C}^{\mathrm{T}}$

Mycoplasma citelli $\mathrm{RG}-2 \mathrm{C}^{\mathrm{T}}$

Mycoplasma cloacale $383^{\mathrm{T}}$

Mycoplasma collis $58 \mathrm{~B}^{\mathrm{T}}$

Mycoplasma columbinasale $694^{\mathrm{T}}$

Mycoplasma columbinum MMP-1 ${ }^{\mathrm{T}}$

Mycoplasma columborale MMP-4 ${ }^{\mathrm{T}}$

Mycoplasma conjunctivae HRC581 ${ }^{\mathrm{T}}$

Mycoplasma cricetuli $\mathrm{CH}^{\mathrm{T}}$

Mycoplasma cynos $\mathrm{H} 831^{\mathrm{T}}$

Mycoplasma dispar $462 / 2^{\mathrm{T}}$

Mycoplasma edwardii PG $24^{\mathrm{T}}$

Mycoplasma equigenitalium $\mathrm{T} 37^{\mathrm{T}}$

Mycoplasma equirhinis M432/72

Mycoplasma fastidiosum $4822^{\mathrm{T}}$

Mycoplasma faucium $\mathrm{DC}^{3} 33^{\mathrm{T}}$

Mycoplasma felifaucium $\mathrm{PV}^{\mathrm{T}}$

Mycoplasma felis $\mathrm{CO}^{\mathrm{T}}$

Mycoplasma fermentans $\mathrm{PG} 18^{\mathrm{T}}$

Mycoplasma flocculare $\mathrm{Ms} 42^{\mathrm{T}}$

Mycoplasma gallinaceum $\mathrm{DD}^{\mathrm{T}}$

Mycoplasma gallinarum PG16 $^{\mathrm{T}}$

Mycoplasma gallisepticum PG31 ${ }^{\mathrm{T}}$

Mycoplasma gallopavonis WR1 ${ }^{\mathrm{T}}$

Mycoplasma gateae $\mathrm{CS}^{\mathrm{T}}$

Mycoplasma genitalium $\mathrm{G}^{3} 7^{\mathrm{T}}$

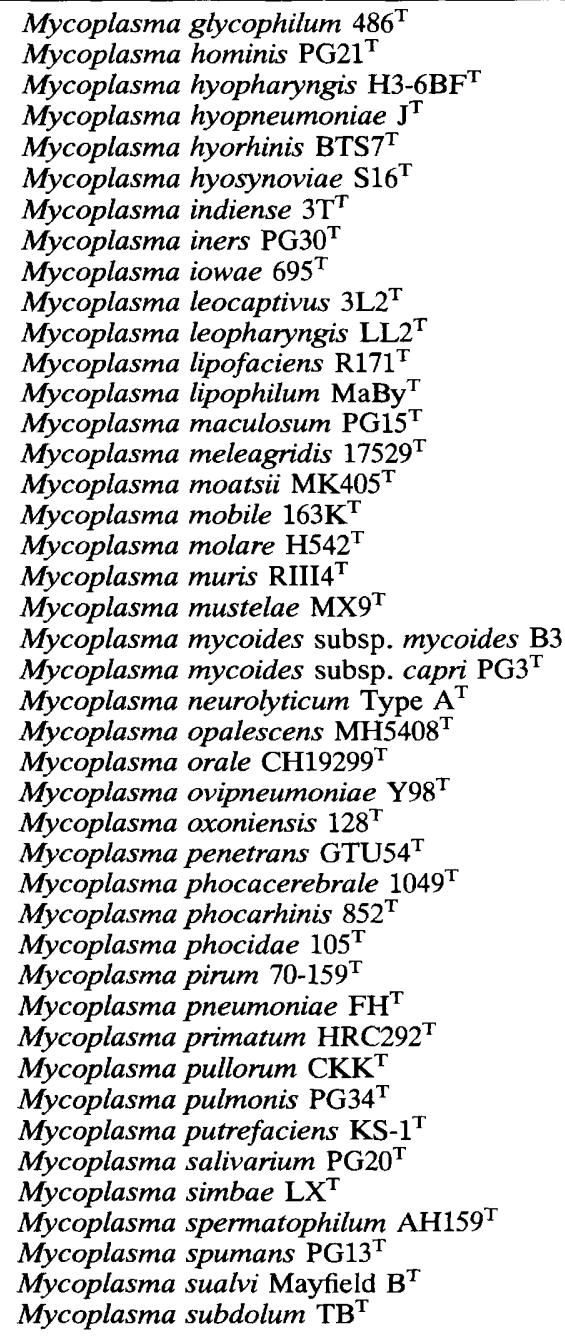

Mycoplasma glycophilum $486^{\mathrm{T}}$

Mycoplasma hominis $\mathrm{PG} 21^{\mathrm{T}}$

Mycoplasma hyopharyngis $\mathrm{H} 3-6 \mathrm{BF}^{\mathrm{T}}$

Mycoplasma hyopneumoniae $\mathrm{J}^{\mathrm{T}}$

Mycoplasma hyorhinis $\mathrm{BTS}^{\mathrm{T}}$

Mycoplasma hyosynoviae $\mathrm{S} 16^{\mathrm{T}}$

Mycoplasma indiense $3 \mathrm{~T}^{\mathrm{T}}$

Mycoplasma iners PG30 ${ }^{\mathrm{T}}$

Mycoplasma iowae $695^{\mathrm{T}}$

Mycoplasma leocaptivus $3 \mathrm{~L} 2^{\mathrm{T}}$

Mycoplasma leopharyngis $\mathrm{LL}_{2}^{\mathrm{T}}$

Mycoplasma lipofaciens $\mathrm{R} 171^{\mathrm{T}}$

Mycoplasma lipophilum $\mathrm{MaBy}^{\mathrm{T}}$

Mycoplasma maculosum PG15

Mycoplasma meleagridis $17529^{\mathrm{T}}$

Mycoplasma moatsii MK $405^{\mathrm{T}}$

Mycoplasma mobile $163 \mathrm{~K}^{\mathrm{T}}$

Mycoplasma molare $\mathrm{H} 542^{\mathrm{T}}$

Mycoplasma muris RIII4 ${ }^{\mathrm{T}}$

Mycoplasma mustelae $\mathrm{MX} 9^{\mathrm{T}}$

Mycoplasma mycoides subsp. mycoides B3

Mycoplasma mycoides subsp. capri $\mathrm{PG}^{\mathrm{T}}$

Mycoplasma neurolyticum Type $\mathrm{A}^{\mathrm{T}}$

Mycoplasma opalescens MH5408

Mycoplasma orale $\mathrm{CH} 19299^{\mathrm{T}}$

Mycoplasma ovipneumoniae $\mathrm{Y}^{\mathrm{T}} 8^{\mathrm{T}}$

Mycoplasma oxoniensis $128^{\mathrm{T}}$

Mycoplasma penetrans GTU54 $4^{\mathrm{T}}$

Mycoplasma phocacerebrale $1049^{\mathrm{T}}$

Mycoplasma phocarhinis $852^{\mathrm{T}}$

Mycoplasma phocidae $105^{\mathrm{T}}$

Mycoplasma pirum $70-159^{\mathrm{T}}$

Mycoplasma pneumoniae $\mathrm{FH}^{\mathrm{T}}$

Mycoplasma primatum $\mathrm{HRC} 292^{\mathrm{T}}$

Mycoplasma pullorum CKK $^{\mathrm{T}}$

Mycoplasma pulmonis PG34

Mycoplasma putrefaciens $\mathrm{KS}-1^{\mathrm{T}}$

Mycoplasma salivarium $\mathrm{PG}^{\mathrm{T}}{ }^{\mathrm{T}}$

Mycoplasma simbae $\mathrm{LX}^{\mathrm{T}}$

Mycoplasma spermatophilum $\mathrm{AH} 159^{\mathrm{T}}$

Mycoplasma spumans PG13 ${ }^{\mathrm{T}}$

Mycoplasma sualvi Mayfield $\mathrm{B}^{\mathrm{T}}$

Mycoplasma subdolum $\mathrm{TB}^{\mathrm{T}}$

Mycoplasma synoviae WVU $1853^{\mathrm{T}}$

Mycoplasma testudinis $01008^{\mathrm{T}}$

Mycoplasma verecundum $107^{\mathrm{T}}$

Mycoplasma sp. California (calf joint)

Mycoplasma sp. B5P (bovine joint)

Mycoplasma sp. F38 (caprine lung)

Mycoplasma sp. M7806 (cat oropharynx)

Mycoplasma sp. 3306 (ovine genitals)

Mycoplasma sp. HRC291 (primate throat)

Mycoplasma sp. 3446 (bovine fetus)

Mycoplasma sp. B689 (canine throat)

Mycoplasma sp. GM257A (caprine ear)

Mycoplasma sp. Utah C (tortoise nasal area)

Acholeplasma axanthum S-743 ${ }^{\mathrm{T}}$

Acholeplasma cavigenitalium $\mathrm{GP}^{\mathrm{T}}$

Acholeplasma equifetale $\mathrm{C}_{112}{ }^{\mathrm{T}}$

Acholeplasma granularum BTS39 ${ }^{\mathrm{T}}$

Acholeplasma hippikon $\mathrm{C}^{\mathrm{T}}$

Acholeplasma laidlawii $\mathrm{PG} 8^{\mathrm{T}}$

Acholeplasma modicum $\mathrm{PG} 49^{\mathrm{T}}$

Acholeplasma morum 72-043

Acholeplasma multilocale PN525 ${ }^{\mathrm{T}}$

Acholeplasma oculi $19 \mathrm{~L}^{\mathrm{T}}$

Acholeplasma parvum $\mathrm{H}_{23} \mathrm{M}^{\mathrm{T}}$

Acholeplasma sp. 0502-C1 (broccoli plant)

Acholeplasma sp. J233 (coconut palm)

Entomoplasma melaleucae $\mathrm{M} 1^{\mathrm{T}}$

Entomoplasma ellychniae ELCN-1 ${ }^{\mathrm{T}}$

Entomoplasma lucivorax PIPN-2 ${ }^{\mathrm{T}}$

Entomoplasma luminosum PIMN-1 ${ }^{\mathrm{T}}$

Entomoplasma somnilux PYAN-1 ${ }^{\mathrm{T}}$

Mesoplasma florum $\mathrm{L1}^{\mathrm{T}}$

Mesoplasma entomophilum $\mathrm{TAC}^{\mathrm{T}}$

Mesoplasma seiffertii $\mathrm{F}^{\mathrm{T}}$

Mesoplasma lactucae $831-\mathrm{C} 4^{\mathrm{T}}$

Mesoplasma sp. PS-1 (dipteron larva)

Mesoplasma sp. YJS (syrphid fly)

Mesoplasma sp. PUPA-2 (Pup29g) (firefly gut)

Mesoplasma sp. CHPA-2 (soldier beetle gut)

Mesoplasma sp. ELCA-2 (firefly gut)

Mesoplasma sp. GRUA-1 (longhorn beetle)

Mesoplasma sp. BARC-779 (beetle)

Mesoplasma sp. BARC-857 (tabanid)

${ }^{a}$ Data are from Mycoplasma Section, Laboratory of Molecular Microbiology, National Institute of Allergy and Infectious Diseases, Frederick, Md. Sites of isolation are in parentheses.

16S rRNA gene was compared with the entire GenBank data base (release 73). The nucleotide sequences of the 16S rRNA gene from more than 40 mycoplasmal species are known, and the BV1 sequence was found to be unique. The BV1 sequence was aligned to 16S RNA sequences in the data base with the Genetics Computer Group program FASTA and the MacVector software with similar results. The strain BV1 gene was most similar to the 16S rRNA genes within the Mycoplasma lipophilum cluster of the hominis group of mycoplasmas (37). The best alignments were with the sequences from $M$. synoviae and Mycoplasma bovigenitalium, which shared, respectively, 92 and $89 \%$ identity with the strain BV1 gene.

\section{DISCUSSION}

The typical fried-egg-like colony shape, lack of a cell wall, failure to revert to a cell wall form, and filterability through 220- to 450-nm-pore-size filters were consistent with placement of strain BV1 within the order Mycoplasmatales (15). Dependence on sterol as a growth factor and sensitivity to digitonin lysis further identified strain BV1 as belonging to the family Mycoplasmataceae. Its general biochemical properties and lack of an enzyme system to hydrolyze urea conformed to the criteria necessary to include the isolate within the genus Mycoplasma.

Strain BV1 was serologically distinct from previously named representative members of the genera Mycoplasma, Acholeplasma, Entomoplasma, and Mesoplasma as well as strains belonging to these genera but not identified to species level. It was also serologically distinct from nine previously characterized avian species that belong to the genus $\mathrm{Myco}$ plasma. The nucleotide sequence of the strain BV1 $16 \mathrm{~S}$ rRNA gene compared with the $16 \mathrm{~S}$ rRNA gene sequences of more than 40 known mycoplasmal species indicated a relationship to $M$. synoviae and $M$. bovigenitalium. The protein profile showed a distinctive pattern when compared with six recognized avian mycoplasma species. Since strain BV1 was first isolated from a new avian host, the free-living black vulture $C$. atratus, we conclude that the isolate represents a new species and propose the name $M$. corogypsi (co.ro.gyp. si. Gr. n. koros, a raven [black]; Gr. n. gyps, a vulture; N.L. 


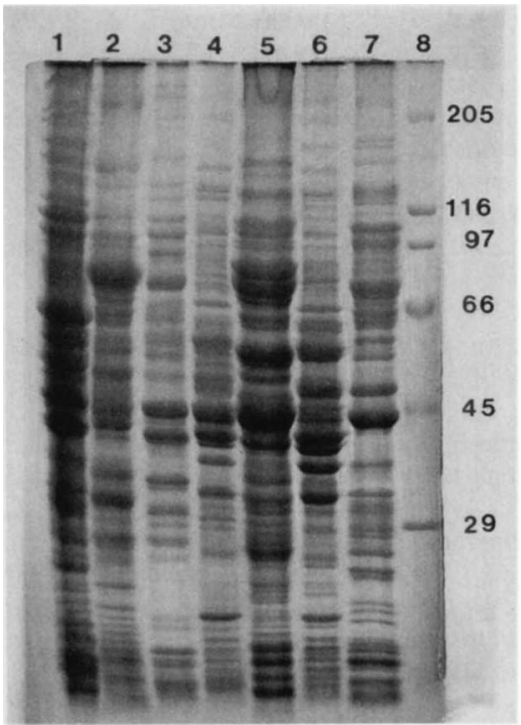

FIG. 3. Coomassie blue-stained electrophoretic patterns. Lanes: 1, M. gallisepticum ATCC $19610^{\mathrm{T}} ; 2$, M. synoviae ATCC $25204^{\mathrm{T}} ; 3$, $M$. gallinarum ATCC $19708^{\mathrm{T}} ; 4, M$. gallinaceum ATCC $33550^{\mathrm{T}} ; 5$, M. meleagridis ATCC $25294^{\mathrm{T}} ; 6, M$. iowae ATCC $33552^{\mathrm{T}} ; 7$, strain BV1; 8, molecular weight standards (in thousands).

gen. n. corogypsi, of raven vultures) for taxonomic purposes.

Description of $M$. corogypsi sp. nov. $M$. corogypsi (co. ro.gyp'si. Gr.n. Koros, a raven [black]; Gr. n. gyps, a vulture; N.L. gen. n. corogypsi, of raven vultures). Cells are pleomorphic, irregular, elongated, or elliptical ( 0.3 to 2.0 by 0.2 to $0.6 \mu \mathrm{m}$ ) and show small circular budding processes abutting the elongated cells. Cells lack a true cell wall and are bounded by a single trilaminar membrane.

Colonies on solid Frey medium have a fried-egg-like appearance and range in size from 20 to $450 \mu \mathrm{m}$ in diameter.

Chemoorganotroph. Acid is produced from glucose. Arginine and urea are not hydrolyzed. Film and spot reaction negative.

Cholesterol or serum is required for growth.

Optimum growth occurs at $37^{\circ} \mathrm{C}$ in an atmosphere of $10 \%$ $\mathrm{CO}_{2}$ and air.

Hemadsorbs and hemagglutinates chicken, guinea pig, sheep, and human erythrocytes.

Serologically distinct by the growth inhibition test from previously named representative members of the genera Mycoplasma, Acholeplasma, Entomoplasma, and Mesoplasma as well as strains belonging to these genera but not identified to species level.

Isolated from the exudate of a footpad abscess of a black vulture ( $C$. atratus).

The base composition (guanine-plus-cytosine content) of the DNA is $28 \mathrm{~mol} \%$ as determined by the buoyant density method.

A cloned culture of $M$. corogypsi (ATCC 51148 ${ }^{\mathbf{T}}$ ) has been deposited as the type strain in the national collection of type cultures, the American Type Culture Collection.

\section{ACKNOWLEDGMENTS}

This research was supported by Food Animal Health and Disease Research grant AL-V-210, from the College of Veterinary Medicine, to V.S.P. and Public Health Service grant AI25640 to K.D. from the National Institutes of Health. Synthesis of DNA primers was supported by NCI grant CA13148 to the University of Alabama at Birmingham (UAB) Comprehensive Cancer Center. The Genetics Computer Group programs were made available to us through the UAB Center for AIDS Research, supported by PHS grant AI27767.

\section{REFERENCES}

1. Aluotto, B. B., R. G. Wittler, C. O. Williams, and J. E. Faber. 1970. Standardized bacteriologic techniques for characterization of Mycoplasma species. Int. J. Syst. Bacteriol. 20:35-58.

2. Bolske, G., and T. Morner. 1982. Isolation of a Mycoplasma sp. from three buzzards (Buteo spp.). Avian Dis. 26:406 411.

3. Clyde, W. A., Jr. 1983. Growth inhibition tests, p. 405-410. In S. Razin and J. G. Tully (ed.), Methods in mycoplasmology, vol. 1. Academic Press, Inc., New York.

4. Devereux, J., P. Haeberli, and O. Smithies. 1984. A comprehensive set of sequence analysis programs for the VAX. Nucleic Acids Res. 12:387-395.

5. Dienes, L. 1967. Permanent stained agar preparations of mycoplasma and L-forms of bacteria. J. Bacteriol. 93:689-692.

6. Dybvig, K., and J. Alderete. 1988. Transformation of Mycoplasma pulmonis and Mycoplasma hyorhinis: transposition of Tn916 and formation of cointegrate structures. Plasmid 20:33 41.

7. Dybvig, K., J. W. Simecka, H. L. Watson, and G. H. Cassell. 1989. High-frequency variation in Mycoplasma pulmonis colony size. J. Bacteriol. 171:5165-5168.

8. Dybvig, K., and A. Woodard. 1992. Cloning and DNA sequence of a mycoplasmal rec $A$ gene. J. Bacteriol. 174:778-784.

9. Edward, D. G., and A. D. Kanarek. 1960. Organisms of the pleuropneumonia group of avian origin: their classification into species. Ann. N.Y. Acad. Sci. 79:696-702.

10. Fallon, R. J., and P. Whittlestone. 1969. Isolation, cultivation and maintenance of mycoplasmas, p. 211-267. In J. R. Norris and D. W. Robbins (ed.), Methods in microbiology, vol. 3B. Academic Press, Inc., New York.

11. Freundt, E. A., B. E. Andrew, H. Ernø, M. Kunze, and F. T. Black. 1973. The sensitivity of Mycoplasmatales to sodium polyanethol-sulfonate and digitonin. Zentralbl. Bakteriol. Parasitenkd. Infektionskr. Hyg. Abt. 1 Orig. Reihe A 225:104-112.

12. Frey, M. L., R. P. Hanson, and D. P. Anderson. 1968. A medium for the isolation of avian mycoplasmas. Am. J. Vet. Res. 19:2163-2171.

13. Gardella, R. S., and R. A. Del Giudice. 1983. Hemagglutination, hemadsorption, and hemolysis, p. 379-381. In S. Razin and J. G. Tully (ed.), Methods in mycoplasmology, vol. 1. Academic Press, Inc., New York.

14. Herrmann, R. 1992. Genome structure and organization, p. 157-168. In J. Maniloff, R. N. McElhaney, L. R. Finch, and J. B. Baseman (ed.), Mycoplasmas: molecular biology and pathogenesis. American Society for Microbiology, Washington, D.C.

15. International Committee on Systematic Bacteriology Subcommittee on the Taxonomy of Mollicutes. 1979. Proposal of minimal standards for descriptions of new species of the class Mollicutes. Int. J. Syst. Bacteriol. 29:172-180.

16. Jordan, F. T. W. 1979. Avian mycoplasmas, p. 1-48. In J. G. Tully and R. T. Whitcomb (ed.), The mycoplasmas, vol. 2. Academic Press, Inc., New York.

17. Jordan, F. T. W., H. Ernø, G. S. Cottew, K. H. Hinz, and L. Stipkovits. 1982. The characterization and taxonomic description of five mycoplasma serotypes of avian origin and their elevation to species rank and further evaluation of the taxonomic status of Mycoplasma synoviae. Int. J. Syst. Bacteriol. 32:108-115.

18. Jordan, F. T. W., J. N. Howse, M. P. Adams, and O. O. Fatunmbi. 1981. The isolation of Mycoplasma columbinum and $M$. columborale from feral pigeons. Vet. Rec. 109:450.

19. Kirchhoff, H., P. Beyene, M. Fischer, J. Flossdorf, J. Heitmann, B. Khattab, D. Lopatta, R. Rosengarten, G. Seidel, and C. Yousef. 1987. Mycoplasma mobile sp. nov., a new species from fish. Int. J. Syst. Bacteriol. 37:192-197.

20. Koshimizu, K., and T. Magaribuchi. 1977. Isolation of ureaplasma (T-mycoplasma) from the chicken and jungle-fowl. Jpn. 
J. Vet. Sci. 39:195-199.

21. Laemmli, U. K. 1970 . Cleavage of structural proteins during the assembly of the head of bacteriophage T4. Nature (London) 227:680-685.

22. Markwell, M. K., S. M. Haas, L. L. Bieber, and N. E. Tolbert. 1978. A modification of the Lowry procedure to simplify protein determination in membrane and lipoprotein samples. Anal. Biochem. 87:206-210.

23. Messing, J., R. Crea, and P. H. Seeburg. 1981. A system for shotgun DNA sequencing. Nucleic Acids Res. 9:309-321.

24. Norrander, J., T. Kempe, and J. Messing. 1983. Construction of improved M13 vectors using oligonucleotide-directed mutagenesis. Gene 26:101-106.

25. Pascucci, S., N. Maestrini, S. Govoni, and A. Prati. 1976. Mycoplasma synoviae in the guinea-fowl. Avian Pathol. 5:291297.

26. Razin, S. 1983. Biochemical and enzymatic tests in mycoplasma identification, p. 335-391. In S. Razin and J. G. Tully (ed.), Methods in mycoplasmology, vol. 1. Academic Press, Inc., New York.

27. Razin, S., and E. A. Freundt. 1984. The mycoplasmas, p. 740-792. In N. R. Kreig and J. G. Holt (ed.), Bergey's manual of systematic bacteriology, vol. 1. The William and Wilkins Co., Baltimore, Md.

28. Razin, S., and J. G. Tully. 1970. Cholesterol requirement of mycoplasmas. J. Bacteriol. 102:306-310.

29. Sambrook, J., E. F. Fritsch, and T. Maniatis. 1989. Molecular cloning: a laboratory manual, 2nd ed. Cold Spring Harbor Laboratory, Cold Spring Harbor, N.Y.

30. Scharf, S. J. 1990. Cloning with PCR, p. 84-91. In M. A. Innis,
D. H. Gelfand, J. J. Sninsky, and T. J. White (ed.), PCR protocols: a guide to methods and applications. Academic Press, Inc., San Diego, Calif.

31. Schildkraut, C. L., J. Marmur, and P. Doty. 1962. Determination of the base composition of deoxyribonucleic acid from its buoyant density in CsCl. J. Mol. Biol. 4:430-443.

32. Sobeslavsky, O., B. Prescott, and R. M. Chanock. 1968. Adsorption of Mycoplasma pneumoniae to neuraminic acid receptors of various cells and possible role in virulence. J. Bacteriol. 96:695-705.

33. Sprunt, A., and E. B. Chamberlain. 1970. South Carolina bird life, p. 149-152. University of South Carolina Press, Columbia.

34. Stipkovits, L., A. A. El-Ebeedy, J. Kisary, and L. Varga. 1975. Mycoplasma infection of geese. I. Incidence of mycoplasmas and acholeplasmas in geese. Avian Pathol. 4:35-43.

35. Tully, J. G., R. F. Whitcomb, H. F. Clark, and D. L. Williamson. 1977. Pathogenic mycoplasmas: cultivation and vertebrate pathogenicity of a new spiroplasma. Science 195:892-894.

36. Weisburg, W. G., S. M. Barns, D. A. Pelletier, and D. J. Lane. 1991. 16S ribosomal DNA amplification for phylogenetic study. J. Bacteriol. 173:697-703.

37. Weisburg, W. G., J. G. Tully, D. L. Rose, J. P. Petzel, H. Oyaizu, D. Yang, L. Mandelco, J. Sechrest, T. G. Lawrence, J. Van Etten, J. Maniloff, and C. R. Woese. 1989. A phylogenetic analysis of the mycoplasmas: basis for their classification. J. Bacteriol. 171:6455-6467.

38. Yamamoto, R., C. H. Bigland, and H. B. Ortmayer. 1965. Characteristics of Mycoplasma meleagridis sp. $\mathrm{n}$. isolated from turkeys. J. Bacteriol. 90:47-49. 